\title{
The Effect of a Shift on the Frequency of Transduced Salmonella typhimurium Cells in the Early Period of Transduction
}

\author{
BY J. HUBÁ̌̌EK \\ Department of Microbial Genetics and Variability, Institute of \\ Microbiology, Czechoslovak Academy of Sciences, Na cvičišti 2, Praha 6
}

(Received 4 January 1963)

\begin{abstract}
SUMMARY
The frequency of transduced cells $\left(\mathrm{gal}^{+}\right)$was reduced by the transfer of the Salmonella typhimurium recipient cells with adsorbed P22 transducing phage from a complete into a minimal medium. This reduction was most conspicuous immediately after the adsorption of the phage $(3 \mathrm{~min}$.$) and$ then gradually decreased as transfer was delayed. After cultivation for 90 min. under conditions which permitted growth and multiplication of the cells the frequency of the transduced cells was practically no more influenced. The sensitivity of the potentially transduced cells to acriflavine was assayed soon after the adsorption of the phage. An early acriflavinereversible phase was demonstrated in more than $50 \%$ of transductions. A close time relationship was found between shift-reversible and acriflavinereversible phases.
\end{abstract}

\section{INTRODUCTION}

The final product of a stable transduction by the P22 phage is a recombined microbial cell which transfers the new marker obtained by transduction into all its progeny. It is assumed that the first step which leads to such a recombinant, i.e. the injection of deoxyribonucleic acid (DNA) of the transducing particles into the recipient cell, is analogous to the first stage of any phage infection. The second stage, i.e. the mechanism of the incorporation of the transduced fragment into the genetic apparatus of the recipient cell and the period during which the integration processes occur, is the main problem of the genetics of transduction.

Very little is known about what happens after the penetration of the transducing element into the recipient cell. In transduction of motility to non-motile Salmonella cells the first motile recombinants appear in about three generations after phage adsorption (Stocker, 1958). In studying the mechanism of transduction of galactose fermentation it was found that during the period in which the viable count of the culture increased $c a$. 32-fold the increase in the number of transductants was less, by a factor of 2-4 (Hubáček, 1961; Hubáček \& Málek, 1962). The further results support our opinion that the potentially transduced cells divide at about the same rate as the rest of the population and during the first five divisions gal- (untransduced) cells are segregated (Hubáček, 1962). Delayed gene incorporation, which probably takes place during the first two divisions, and nuclear segregation may account for 'the lower number of divisions of transduced cells'.

This paper reports some experiments in which we succeeded in reducing the 
frequency of transduced cells by a method which in its principle is similar to the 'shift-down' method (Maaløe, 1960), i.e. by transfer of a suspension of cells soon after the adsorption of the transducing phage from a complete to a minimal medium. The clarification of the nature of this effect might produce information about the processes leading to incorporation of the transducing element into the genetic apparatus of the cell. For the purpose of timing the period of incorporation the elimination of the free transducing element by acriflavine (Hirota \& Iijima, 1957) has been followed.

\section{METHODS}

Bacterial and phage stocks. Strains of Salmonella typhimurium sw351, LT2 (Zinder \& Lederberg, 1952) and sw $351 \mathrm{r}$ were used; sw $351\left(\mathrm{gal}^{-}\right)$is an auxotrophic mutant of strain LT 22 , lysogenic and carries $P 22$ phage. The strain Sw351 R is a prototrophic back mutant of the auxotrophic strain sw351. In liquid minimal medium it grows only slowly and on minimal agar produces only small colonies. Phage lysates used were P22 grown on LT 2 ( $\mathrm{gal}^{+}$) strain and were made as described by Zinder \& Lederberg (1952). The lysates were sterilized by filtration or by chloroform treatment. Prior to the experiment chloroform was removed by aeration for $30 \mathrm{~min}$. at $37^{\circ}$. The sterility of the lysate was tested on nutrient agar. Phage titrations were made by the soft-agar-layer method (Adams, 1950).

Media. The phage was assayed in soft complete agar $(0.7 \%)$ laid over a complete bottom-layer agar. Bacterial recipients were grown on complete agar. Transductions were assayed on eosin-methylene-blue agar (EMB) with galactose. All the minimal and complete, liquid or solid, media used were as described by Lederberg (1950); in the minimal medium $\mathrm{MgSO}_{4}$ was replaced by $0.01 \%$ of $\mathrm{MnCl}_{2}$, which was added in this concentration to all other media which were used for transduction. For the elimination of the transducing element by acriflavine Difco broth was used (Hirota \& Iijima, 1957).

Transduction experiments. In all experiments high numbers of cells and phage had to be used because of the low frequency of the transduced cells ( $10^{-6} /$ recipient) which is characteristic for this type of transduction. $0.1 \mathrm{ml}$. of a 'starved' suspension of the recipient cells $\left(2 \cdot 0-6 \cdot 0 \times 10^{10} / 0 \cdot 1 \mathrm{ml}\right.$. $)$, obtained by washing the $48 \mathrm{hr}$. culture of sw351 or sw351 R strain from complete agar by saline, was mixed with $9.9 \mathrm{ml}$. of a phage suspension in a complete medium. This ratio has also been maintained when preparing a larger amount of the suspension of cells with the adsorbed phage. The titre of the phage stocks used in the experiments was $1 \cdot 0$ $2.5 \times 10^{10} / \mathrm{ml}$, the multiplicity $1-6$. The phage was adsorbed for $3,10,15,30$ or $60 \mathrm{~min}$. at $37^{\circ}$.

The elimination of the transducing element by acriflavine. The phage was adsorbed for $10 \mathrm{~min}$. under the conditions stated above. The cell suspension was then pipetted in $1.3 \mathrm{ml}$. amounts into flasks containing $63.7 \mathrm{ml}$. of the complete medium which were then incubated at $37^{\circ}$ without aeration. At intervals from 0 to $150 \mathrm{~min}$., $65 \mathrm{ml}$. samples were centrifuged in the cold; the sediment was then made up to $10 \mathrm{ml}$. and divided into two parts. One part of each sample was assayed for viable count and number of transductants. The cells in the other part of each sample were

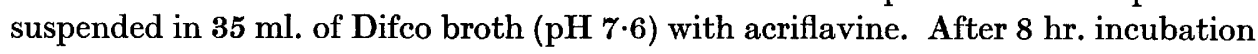
at $37^{\circ}$ without aeration the cells were centrifuged, washed with the complete 
medium and the sediment suspended in $0.65 \mathrm{ml}$. of complete medium. Then the viable count and number of transductants were determined. From the viable count and number of transduced cells in the untreated control part of the sample $\left(N_{u}\right)$ and after acriflavine treatment $\left(N_{a}\right)$ the ratio $N_{a}: N_{u}$ was calculated. The stock aqueous solution of acriflavine $(500 \mu \mathrm{g} . / \mathrm{ml}$.) was sterilized in an autoclave.

Viable count. Samples of $0 \cdot 1 \mathrm{ml}$. were spread on pre-dried nutrient agar plates. The number of transduced $\left(\mathrm{gal}^{+}\right)$cells was determined by spreading $\mathbf{0 \cdot 2} \mathrm{ml}$. samples of the suspension on each of three pre-dried EMB galactose plates.

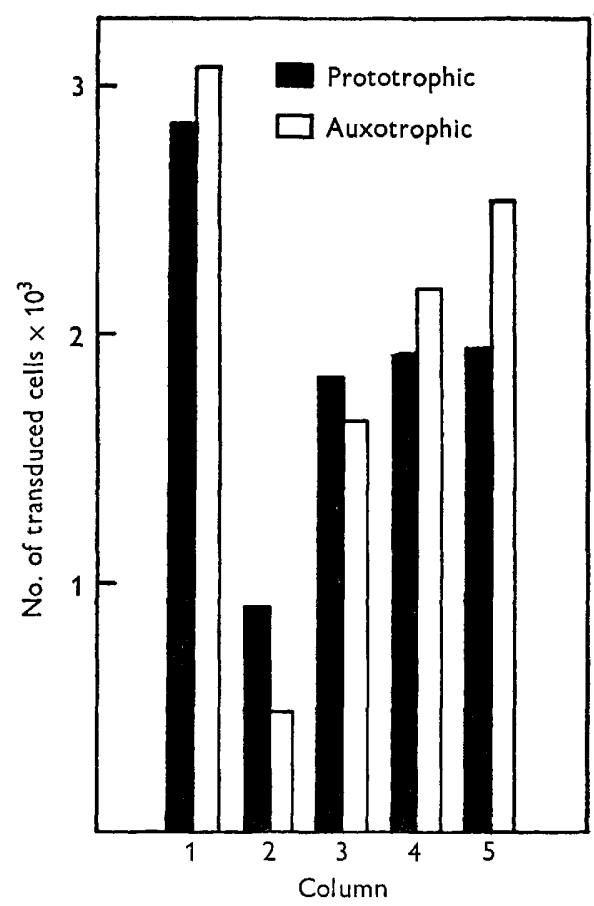

Fig. 1. The influence of various cultivation media on the frequency of the transduced cells. Two recipient strains of Salmonella typhimurium ( $\mathrm{gal}^{-}$) were used. The phage was adsorbed for $15 \mathrm{~min}$. at $37^{\circ}$ in complete medium and then $1 \mathrm{ml}$. samples of the suspension were pipetted into: complete medium (column 1); minimal medium (column 2); minimal medium with $10 \mathrm{mg} . / \mathrm{ml}$. casein hydrolysate (column 3); minimal medium with $5 \mathrm{mg} . / \mathrm{ml}$. of yeast extract (column 4); minimal medium with both yeast extract and casein hydrolysate (column 5). The cells in the samples were centrifuged in the cold, washed and suspended in $1 \mathrm{ml}$. of the above-mentioned media. The suspensions were exposed for $90 \mathrm{~min}$. at $37^{\circ}$ and the viable count and the number of transductants were determined. The columns of $\mathrm{gal}^{+}$transductants are expressed per $2.9 \times 10^{9}$ (auxotrophic) and $3.6 \times 10^{9}$ (prototrophic) cells in suspensions.

\section{RESULTS}

The influence of minimal medium on the frequency of transduced cells during the early phase following the adsorption of the phage. By transferring the recipient Salmonella typhimurium cells with the adsorbed P22 transducing phage from a complete into a minimal medium and subsequently incubating them for $90 \mathrm{~min}$. at $37^{\circ}$, the frequency of transduced $\left(\mathrm{gal}^{+}\right)$cells was reduced. The results of a single typical experiment are shown in Fig. 1. In the auxotrophic strain the difference in 
the number of transduced cells between the complete and the minimal medium was more marked. The reduction of the number of transduced cells in the minimal medium was to a great extent abolished by supplementing with casein hydrolysate and/or yeast extract.

The object of later experiments was to establish for how long after the adsorption of the phage the sensitivity of the transduced cells to the minimal medium persisted. Figure $2 A$ shows a plot of the whole number of cells and the number of transduced

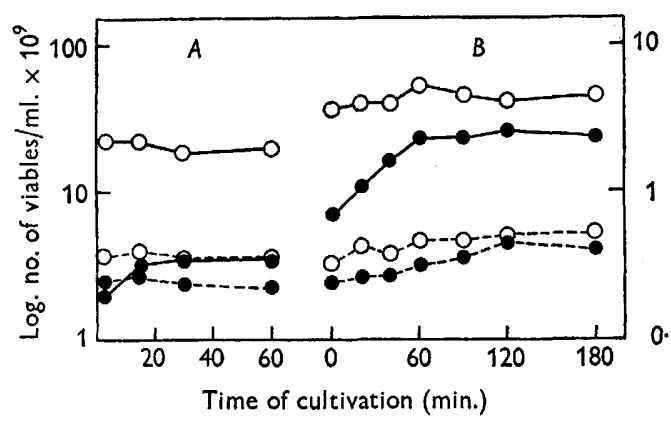

Fig. 2

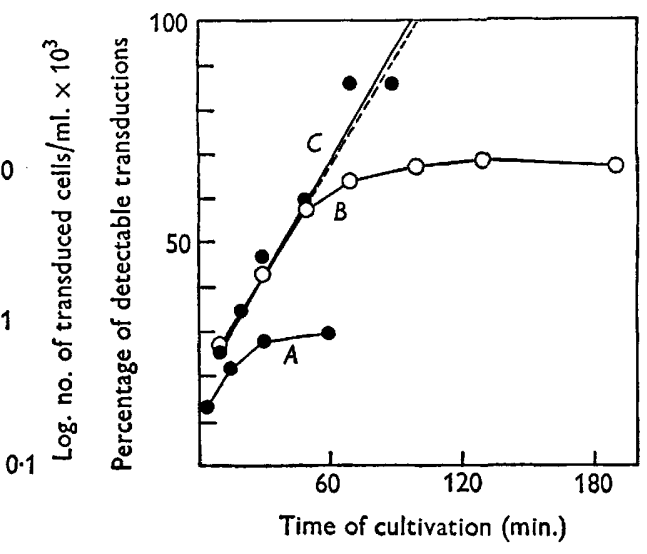

Fig. 3

Fig. 2. Total number of cells and number of transduced cells in complete and minimal medium during early periods of cultivation after phage adsorption. $A$, Recipient cells of strain sw $351 \mathrm{R}\left(0.1 \mathrm{ml}\right.$. suspension; $7 \cdot 3 \times 10^{10}$ cells $)$ were mixed with phage $(16.8 \mathrm{ml}$. of phage suspension in complete medium; $4.2 \times 10^{11}$ of phage particles). After 3,15 , 30 and $60 \mathrm{~min}$. of adsorption $1 \mathrm{ml}$. samples were taken. After washing the cells were suspended in $1 \mathrm{ml}$. of complete $(O)$ or minimal medium (O), exposed for $90 \mathrm{~min}$. at $37^{\circ}$ and the viable count (--) and the number of transduced cells $(-)$ then determined. $B$, Recipient cells of strain sw $351 \mathrm{R}$ were mixed with the phage; after $10 \mathrm{~min}$. of adsorption the suspension was diluted $5 \times$ with complete medium and incubated at $37^{\circ}$. Samples taken were washed in complete $(O)$ or minimal (O) medium and resuspended in these media to original volume. In complete medium the viable count (---) and the number of transduced cells (-) were assayed at once; in minimal medium this was done after $90 \mathrm{~min}$, exposure at $37^{\circ}$.

Fig. 3. The percentage of transduced cells detectable after $90 \mathrm{~min}$. exposure in the minimal medium at certain periods after adsorption. $A$, Undiluted cell suspension (experimental conditions see Fig. $2 A$ ). $B$, Cell suspension diluted $5 \times$ (experimental conditions see Fig. $2 B$ ). $C$, After 10 min. adsorption the suspension of cells with phage diluted $50 \times$ with complete medium and incubated at $37^{\circ}$. At intervals samples were taken and chloramphenicol added (final concentration $15 \mu \mathrm{g} . / \mathrm{ml}$.). The cells were centrifuged and the sediment made up to $10 \mathrm{ml}$. and divided. One part was assayed at once for viable count and number of transductants. The cells in the other part were centrifuged, washed and suspended in $0.65 \mathrm{ml}$. of minimal medium; after $90 \mathrm{~min}$. at $37^{\circ}$ the viable count and the number of transduced cells were determined.

cells. Curve $\boldsymbol{A}$ in Fig. 3 indicates the percentage of transductants detectable after exposure to the minimal medium. The results of the experiment show that the sensitivity of transduced cells to shift from complete to minimal medium was highest at the onset of the transducing process $(3 \mathrm{~min}$. after the adsorption of the phage) and then decreased. However, after $30 \mathrm{~min}$. exposure the sensitivity did not decrease any further. This phenomenon seemed to be due to the high concentration of cells in the adsorption mixture. In the next experiment the suspension of cells 
with adsorbed phage was diluted $5 \times$ in complete medium at the end of the adsorption period. In Fig. $2 B$ the number of viable bacteria and the number of transduced cells are plotted; curve $B$ in Fig. 3 represents the percentage of transductants detectable after exposure in the minimal medium. The results show that when the recipient cell suspension had been thus diluted the sensitivity of the transduced cells to transfer from the complete into the minimal medium at first decreased linearly but after $60 \mathrm{~min}$. this decline stopped. Extrapolation of the linear part of the curve suggests that the transduced cells should, theoretically, become insensitive to the minimal medium after about $90 \mathrm{~min}$. of cultivation.

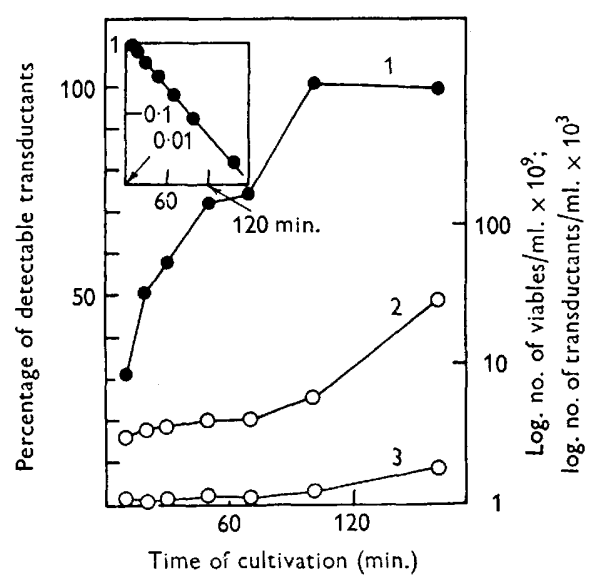

Fig. 4

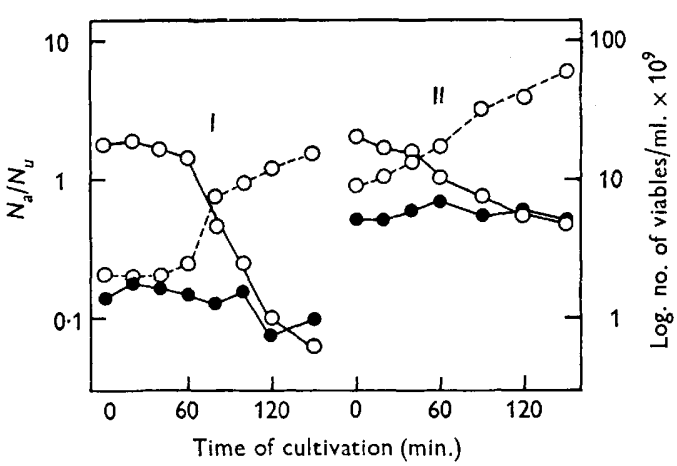

Fig. 5

Fig. 4. The percentage of transduced cells detectable after $90 \mathrm{~min}$. exposure in minimal medium at certain periods of cultivation. Experimental conditions see Fig. $3 C$. The inset in the left corner represents the statistical evaluation of curve 1 by the least squares method and expresses the exponential relation between duration of cultivation and the fraction of transduced cells sensitive to minimal medium.

Fig. 5. The elimination of the transducing element by $8 \mathrm{hr}$. acriflavine treatment at certain periods after adsorption. I, II, number of experiment; $N_{u}$, number of cells in untreated control part of the sample; $N_{a}$ number of cells after acriflavine treatment. $--O_{--}, \log$ number of viable bacteria; - $-\mathrm{O}_{-}, \log N_{a} / N_{u}$ of viable bacteria; - $\log N_{a} / N_{u}$ of transductants.

To confirm this hypothesis experimentally the suspension with adsorbed phage was diluted $50 \times$ with the complete medium. The treatment of these samples was more laborious, however, and even if it was carried out in the cold it required a certain stabilization of the system, at least during the initial transduction stages. From our experiments chloramphenicol was found to be most suitable for this purpose. It did not affect the frequency of transduced cells and did not otherwise interfere with the phenomenon studied here. Curve $C$ in Fig. 3 shows the percentage of transduced cells which persisted after exposure in the minimal medium in relation to the time of preliminary cultivation in complete medium. This curve has a linear character and the sensitivity of transduced cells to minimal medium in fact disappeared after about $90 \mathrm{~min}$. of cultivation. Figure 4 represents the percentage of transduced cells detectable after exposure in the minimal medium (curve 1) and also the number of viable bacteria (curve 2) and of transduced cells 
(curve 3). It appeared again that the sensitivity of the transduced cells to the minimal medium virtually disappeared after about $90 \mathrm{~min}$. of cultivation.

Elimination of the transducing element of the $\mathbf{P} 22$ phage by acriflavine. The timing of the fixation of the transducing element and especially the relationship between this integration process and the period of sensitivity of transduced cells to minimal medium were of the greatest interest here. First the optimal conditions for elimination of the transducing element of $\mathbf{P} 22$ phage had to be found. Experiments were carried out to test $(a)$ the influence, $10 \mathrm{~min}$. after adsorption, of various concentrations of acriflavine, $(b)$ the possibility of an increased elimination by irradiation of the recipient cells after phage adsorption, and $(c)$ the most suitable length of exposure to acriflavine. It had been found that the optimal concentration was 10-15 $\mu \mathrm{g}$. acriflavine $/ \mathrm{ml}$. Irradiation of the recipient cells with adsorbed phage did not increase the effectivity of elimination; it was virtually identical when using the same concentration of acriflavine $(10 \mu \mathrm{g} . / \mathrm{ml}$.) with or without irradiation of the cells. A suitable length of exposure of the cells to acriflavine was $8 \mathrm{hr}$. at $37^{\circ}$ (Table 1).

Table 1. The elimination of the transducing element by acriflavine after 10 min. of phage adsorption

Suspension was irradiated 5 sec. at $50 \mathrm{~cm}$. distance from Philip TUV lamp $30 \mathrm{~W}$; $89 \%$ of cells survived.

Cell suspension with adsorbed phage

\begin{tabular}{|c|c|c|c|c|c|c|}
\hline \multirow[b]{2}{*}{$\begin{array}{l}\text { Exposure } \\
\text { to } \\
\text { acriflavine } \\
\text { (hr.) }\end{array}$} & \multicolumn{3}{|c|}{ Non-irradiated } & \multicolumn{3}{|c|}{ Irradiated } \\
\hline & $\begin{array}{c}\text { No. } \\
\text { bacteria } \\
\times 10^{9} / \mathrm{ml} .\end{array}$ & $\begin{array}{l}\text { No. gal } \\
\text { cells } \\
\times 10^{3} / \mathrm{ml} .\end{array}$ & $\begin{array}{c}\text { Elimination } \\
(\%)\end{array}$ & $\begin{array}{c}\text { No. } \\
\text { bacteria } \\
\times 10^{9} / \mathrm{ml}\end{array}$ & $\begin{array}{l}\text { No. gal } \\
\text { cells } \\
\times 10^{3} / \mathrm{ml} .\end{array}$ & $\begin{array}{c}\text { Elimination } \\
(\%)\end{array}$ \\
\hline 0 & $5 \cdot 6$ & $4 \cdot 0$ & o & $5 \cdot 0$ & $3 \cdot 8$ & 0 \\
\hline 4 & $7 \cdot 2$ & $2 \cdot 7$ & $32 \cdot 5$ & $5 \cdot 3$ & $\mathbf{2} \cdot \mathbf{3}$ & $39 \cdot 3$ \\
\hline 8 & $7 \cdot 0$ & $2 \cdot 1$ & $47 \cdot 5$ & $5 \cdot 1$ & $2 \cdot 0$ & $47 \cdot 7$ \\
\hline 20 & $2 \cdot 5$ & $\mathbf{0 \cdot 2 4}$ & $68 \cdot 0$ & $1 \cdot 7$ & $0 \cdot 2$ & $70 \cdot 0$ \\
\hline
\end{tabular}

In further experiments the relation between cellular growth and sensitivity of the transducing elements to acriflavine was assayed. The results of two such experiments are shown in Fig. 5. After $10 \mathrm{~min}$. of phage adsorption the cell suspension (viable count in expt. $1 \mathrm{ca} .2 \times 10^{9} / \mathrm{ml}$. and in expt. $2 \mathrm{ca} .8 \times 10^{9} / \mathrm{ml}$, to follow the higher number of transductants) was diluted $50 \times$ with complete medium and incubated at $37^{\circ}$. At intervals samples were taken and divided into 2 parts. One part of each sample was treated by acriflavine for $8 \mathrm{hr}$.; the second part served as a control and was not treated by acriflavine. Before the assaying of viable count both suspensions were concentrated to the original volume.

In the early period up to $60 \mathrm{~min}$. of incubation the number of viable bacteria after acriflavine treatment slightly increases $\left(N_{a} / N_{u}>1\right)$ and then the cells become sensitive and the viable count is reduced $\left(N_{a} / N_{u}<1\right)$. The number of transduced cells was most influenced in the initial phase of transduction; after $8 \mathrm{hr}$. exposure it decreased to about $80 \%$ in expt. 1 and to about $50 \%$ in expt. 2. In expt. $112.5 \mu \mathrm{g}$. and in expt. $210 \mu \mathrm{g}$. acriflavine $/ \mathrm{ml}$. were used. This early flavine reversible phase lasts during the $60 \mathrm{~min}$. of cultivation. After this time it could hardly be judged when it ended because of the complication of the onset of sensitivity to acriflavine of the rest of the culture. 


\section{DISCUSSION}

The above experiments have shown that it is possible to reduce the frequency of transduced cells by their exposure to minimal medium. The reduced yield of transductants was not paralleled by reduction in the total number of viable recipient bacteria. This sensitive phase of the potentially transduced cells to the minimal medium resembled the reversible phase as described by Ephrussi-Taylor (1958) in the transformation of pneumococcal cells.

What does the effect of the minimal medium on the frequency of transduced cells consist of? Our latest experiments show that the frequency of transductants was not influenced by the minimal medium itself. This effect was observed only after shift down from complete to minimal medium, but not when the cells after adsorption of the phage in minimal medium were transferred to minimal medium again (Hubáček, 1963). It may be assumed, therefore, that the reduced frequency of transductants after transfer from complete to minimal medium was not due to deficiency of some elements in minimal medium, but rather the result of disturbance in the regulation mechanisms in the cell. In this connexion the experiments of Maaløe (1960) are interesting; it was shown that after shift down repression of metabolic activity takes place.

Possible higher sensitivity of the pre-transductants to spreading (Goldstein, Goldstein, Brown \& Shao-Chia Chou, 1959) was excluded by assaying the galactosepositive transductants in a soft agar layer. According to another interpretation the reduced frequency of transduced cells was not due to the death of the cells but rather results from the 'curing' of the cells from the transducing element. The nature of this event is unknown. Our preliminary experiments have shown that the number of transduced cells was reduced at $0^{\circ}$ as well as $37^{\circ}$. The sudden chilling of the suspension had a stimulating effect and reduced the number of transductants in complete medium. The disturbance in the normal composition of amino acid pool in the starved cell seemed to be the primary cause of this event. But the change in the pool by itself probably did not cause the 'curing' of the cell from the transducing element. The presence of $\mathrm{Mg}^{2+}, \mathrm{Ca}^{2+}, \mathrm{Mn}^{2+}$, cadaverine or putrescine in the minimal medium can reverse the effect of a shift and the frequency of transduced cells remains unchanged (Hubáček, 1963). This stabilization process could be demonstrated only at a higher temperature $\left(22^{\circ}\right.$ or $\left.37^{\circ}\right)$. According to these results it might be speculated that the 'curing' process by itself consists at least of two stages. The first can be carried out at $0^{\circ}$ and the transducing element need not be destroyed. The second one occurs only at higher temperature and may be inhibited by the presence of divalent cations. This hypothesis is being the object of further experiments.

From experiments on the curing effect of chloramphenicol on bacteria infected with different mutants of P22 phage it was concluded that the loss of phage element does not involve the elimination of the phage genome altogether and that the curing effect may be the result of damage to only some cistron or essential replica of it in the phage genome (Ting, 1960). The effect of a shift may be the same in this respect.

The results obtained from experiments with acriflavine showed an early flavinereversible phase in more than $50 \%$ of transductions but did not show exactly when it ends. However, they suggest a conspicuous relationship between shift-reversible and flavine-reversible phases. It may be assumed that the $90 \mathrm{~min}$. phase of 
sensitivity of transductants to transfer to minimal medium is the period in which the transduced element is not integrated into the genome of the recipient cell. In the course of multiplication of the potentially transduced cell in complete medium the fragment is apparently stabilized through integration with the bacterial genome. This period of cell growth required for incorporation agrees well with the results of the work of Jacob \& Wollman (1957), who followed the ability of zygotes in which the DNA from one parent was labelled with ${ }^{32} \mathrm{P}$ to produce recombinants. Our results, however, are not in agreement with the opinion of Hartman \& Kozinski (1962), who suppose that the fast stabilization of complete transducing elements toward ${ }^{32} \mathrm{P}$ decay is caused by the fact that the recombination events take place very rapidly following injection of this particle into recipient bacteria. Since the sensitivity of the DNA of Escherichia coli or Salmonella to destruction by ${ }^{32} \mathrm{P}$ decay is very similar to that of the phage (Stent \& Fuerst, 1956) and as it is assumed that the integration of transducing element requires multiplication of the cells it is not likely that the act of recombination is responsible for the observed early stabilization.

The statistical analysis of the data were done by Mr M. Jílek, to whom thanks are due. The technical assistance of Mr J. König is gratefully acknowledged.

\section{REFERENCES}

Adams, M. H. (1950). Methods of study of bacterial viruses. Meth. med. Res. $2,1$.

Ephrussi-Taylor, H. (1958). The mechanism of deoxyribonucleic acid-induced transformations. Recent Progress in Microbiology. Symp. 7th Int. Congr. Microbiol., p. 51. Stockholm: Almquist and Wiksell.

Goldstein, A, Goldstein, D. B., Brown, B. J. \& Shao-Chia Chou (1959). Amino acid starvation in an Escherichia coli auxotroph. I. Effects on protein and nucleic acid synthesis and on cell division. Biochim. biophys. Acta, 36, 163.

Hartman, P. E. \& Kozinski, A. W. (1962). Effects of P $^{32}$ decay on transduction by Salmonella phage $\mathbf{P}_{22}$. Virology, 17, 233.

Hirota, Y. \& Imıma, T. (1957). Acriflavine as an effective agent for eliminating F-factor in Escherichia coli $\mathbf{K}-12$. Nature, Lond. 180, 655.

HuвÁČ́E, J. (1961). Phenomic delay in transduction of Salmonella typhimurium cell. Nature, Lond. 189, 679.

HuвÁČEK, J. (1962). The mechanism of genetic expression of the new marker in transduction of Salmonella typhimurium. Experientia, 18, 126.

НuвÁ̌̌EK, J. (1963). The effect of $\mathrm{Mg}^{2+}$ on the frequency of transduced Salmonella typhimurium recipient cells transferred from a rich to a poor medium. Fol. microbiol. (in the Press).

HubáČek, J. \& MÁlek, I. (1962). The initial chloramphenicol-sensitive phase in the transduction of Salmonella typhimurium. Fol. microbiol. 7, 26.

JАCOB, F. \& Wollman, E. J. (1957). Genetic and physical determinations of chromosomal segments in Escherichia coli. Symp. Soc. exp. Biol. 12, 75.

LEDERBERg, J. (1950). Isolation and characterization of biochemical mutants of bacteria. Meth. med. Res. 3, 5.

MaAlaE, O. (1960). The nucleic acids and the control of bacterial growth. In Microbial Genetics. Symp. Soc. gen. Microbiol. 10, 272.

Stent, G. S. \& Fuerst, C. R. (1956). Decay of incorporated radioactive phosphorus during development of a temperate bacteriophage. Virology, 2, 737.

Stocker, B. A. D. (1958). Phage-mediated transduction. Recent Progress in Microbiology. Symp. 7th Int. Congr. Microbiol., p. 31. Stockholm: Almquist and Wiksell.

Ting, R. C. (1960). A curing effect of chloramphenicol on bacteria infected with bacteriophage. Virology, 12, 68.

Zinder, N. D. \& Lederberg, J. (1952). Genetic exchange in Salmonella. J. Bact. 64, 679. 